\title{
Picking Low Hanging Fruit? Synergies Between Strategic Quality Management and Corporate Social Responsibility
}

\author{
Dr Talal Alsaif, Assistant Professor \\ Department of Management and MIS, \\ College of Business Administration, \\ University of Hail, \\ Kingdom of Saudi Arabia \\ Dr Barbara M Savage, Senior Lecturer \\ Department of Operations and Systems Management, \\ Faculty of Business and Law, \\ University of Portsmouth, \\ Richmond Building, Portland Street, \\ Portsmouth PO1 3DE \\ United Kingdom \\ Barbara.Savage@port.ac.uk \\ Dr Deborah M Reed, Principal Lecturer \\ Department of Operations and Systems Management, \\ Faculty of Business and Law, \\ University of Portsmouth, \\ Richmond Building, Portland Street, \\ Portsmouth PO1 3DE \\ United Kingdom
}

\begin{abstract}
Purpose: The purpose of this paper is to explore and identify the areas in common between Strategic Quality Management (SQM) and Corporate Social Responsibility (CSR) from the literature. Studying these areas is important to develop any further connection between SQM and CSR because of both the potential for benefit to organisations and society, and in order to minimise resources needed for effective action by capitalising on synergies.

Methodology: Literature Review.

Findings: Identification of opportunities for knowledge transfer between SQM and CSR.

Practical Implications: Synergies between SQM and CSR may offer attractive opportunities to capitalise on prior actions and learning, to enhance the value-added to an organisation and the society in which it operates.

Originality/Value: This evaluation is the initial stage of a more in-depth research study investigating the relationship between and integration of SQM and CSR, and its application in specific contexts.
\end{abstract}

Keywords: Strategic Quality Management, Corporate Social Responsibility, Synergies.

\section{Introduction}

One of the common methods of solving a complex problem is to tackle the smaller issues within the problem first. These quick wins are often described as "picking the low hanging fruit". This method of solving complex problems is the crux of this paper, which examines 
commonalities between Strategic Quality Management (SQM) and Corporate Social Responsibility (CSR) to promote implementation of CSR programmes in organisations that have existing SQM processes in place. The implementation of a CSR programme without existing SQM processes in place is far more complex and is beyond the scope of this paper (Acquier, Valiorgue, \& Daudigeos, 2017; Kim, 2017; Bucur, Maior, \& Mureş, 2013; Street \& Street, 2010; Werther \& Chandler, 2010).

Thus, the goal of the paper is to suggest ways in which an organisation that is already embracing SQM may be able to capitalise on their extant knowledge and practical approaches and simply broaden their strategic vision to encompass the wider aims of CSR, without "reinventing the wheel". Though it is recognised that the synergies identified will not provide a full solution, they should significantly accelerate CSR implementation.

Hence, the methodical approach behind the paper is a focussed discursive literature analysis. This is used to explore the origins of SQM, CSR theories and definitions, and the business case for implementing CSR in organisations that have existing SQM processes. ISO 26000, 9000, 14000 and 18000 are introduced as devices that serve as links between SQM and CSR theories. The review of literature is concluded with a discussion of potential synergies expected if organisations pursue the integration of CSR programmes by way of leveraging existing SQM processes.

In order to do this, the analysis does not attempt full coverage of all quality concepts and approaches, because such a vast scope goes well beyond what is feasible in a single paper. Instead, the literature is used to explore just a few of the potential synergies, so as to provide a focus for more in-depth analysis in the future. The authors have chosen to take a conceptual view of what these two ideas encompass, rather than considering detailed practicalities, though, to some extent, implementational synergies may also emerge. Hence, the guiding question in this study is:

How may the synergies between SQM and CSR simplify an organisation's implementation of CSR when SQM is already in place?

\section{What is SQM and where did it come from?}

The origins of modern quality management lie in the seminal work of Shewhart (1931), when he explored the possibility of using statistical techniques to systematically improve the performance of the production process to produce a higher proportion of acceptable products, thus reducing overheads, particularly in respect of wasted production costs and scrap. While the driver for this was economic, arguably, the consequences are akin to some elements of what we now see as CSR, in that, though the success measurements tended to be financial, many of the savings contributing to them were resource based; for example, reductions in wasted raw materials and production items (power, equipment usage, staff time), plus less scrap that needed to be disposed of. This is one of the principles on which Lean Six Sigma (LSS) is based, though the scope of LSS is much broader than Shewhart's in that it covers complete value chains, rather than only manufacturing processes (Karthi, Devadasan, \& Murugesh, 2011; Marques, Requeijo, Saraiva \& Frazão-Guerreiro, 2013).

While many of the Quality Gurus concentrated mostly on the management issues (for example, Deming, Juran, Feigenbaum and Crosby), Taguchi (1990) can be considered to be the next major contributor to the CSR dimension of quality. He stated that "the total quality loss of a product is the sum of the total monetary loss and the environmental effects the product 
contributes during its entire life" (Taguchi, 1995, p. 225), and went on to explain that this included environmental loss from factors such as pollution. However, these effects can be ameliorated by better design of products and production processes (Marques et al., 2013).

Quality management (QM) is defined as: "coordinated activities to direct and control an organisation with regard to quality" (British Standards Institute, 2015, 3.3.4). Since its development in the early 1950s (Crosby, 1979; Deming, 1994; Feigenbaum \& Feigenbaum, 2003; Juran \& De Feo, 2010), the QM movement has become well established in business and QM approaches have been built into a large number of organisations worldwide (Sirvanci, 2004, p. 382). QM features systematic planning, execution and evaluation by a wide range of operational methods and standards (Ghobadian, Gallear \& Hopkins, 2007, p. 704). In addition, the many national and international quality awards provide models which strengthen the influence of SQM because they are "constructed or validated by empirical means" (Black \& Porter, 1996, p. 1).

QM evolved through several stages of complexity and scope from inspection to Quality Control, to Quality Assurance; then being broadened into the much more holistic Total Quality Management (TQM), which Goetsch and Davis (2016, p. 4) define as: “... an approach to doing business that attempts to maximize the competitiveness of an organization through the continual improvement of the quality of its products, services, people, processes and environment".

When planning organisational strategy, leaders are encouraged to analyse the whole ecosystem in which the organisation operates (Leonard \& McAdam, 2002 \& 2004; Prajogo \& Sohal, 2006). So, given the holistic remit of TQM, it seems obvious that strategic planning might call upon TQM as a diagnostic mechanism for monitoring the current state, but also that it might serve as a delivery system to roll out strategic decisions. Thus, SQM can be identified as the integration of TQM with Corporate Strategic Management (CSM) (Leonard \& McAdam, 2002, p. 507). In this paper, the focus is on the broader SQM which is more consistent with the strategic positioning of CSR. In addition, SQM is considered to subsume less strategic quality approaches such as TQM and QM, as discussed by Juran (1989, chapter 6).

\section{What is CSR?}

In contrast, Corporate Social Responsibility (CSR) is a much more recent idea that is becoming an imperative for many organisations, especially in the aftermath of a number of high-profile events which generated significant levels of adverse publicity for major corporations. For example, Nike was boycotted following reports of abusive labour conditions; Shell Oil faced protests following the deliberate sinking of the Brent Spar oil rig in the North Sea (Porter \& Kramer, 2006, p. 3).

SQM and various Excellence models include the concept of CSR and have introduced it to many organisations. However, CSR is still a long way behind SQM in terms of the establishment of its definition and concepts, although some researchers (Schwarz \& Carroll, 2003; Basu \& Palazzo, 2008; Maon, Lindgreen \& Swaen, 2008; Matten \& Moon, 2008) have attempted to conceptualise CSR and Dahlsrud (2008) attempted to show the similarities across some 37 definitions that were available at that time within the literature.

It is common for a term to mean something different in different contexts and countries, and also that a single meaning may be expressed through several different terms. Thus, terminology differentiation is critical to avoid any confusion or misunderstanding, especially if one dominant meaning for the term has not yet emerged because understanding of the concept 
is still developing, as is the case with CSR. This lack of clarity and consistency means that the concept lacks direction about practical methods to implement and to improve the application of CSR.

The concept of CSR encompasses four aspects: corporate citizenship, environmental care, sustainable development and societal impact results (Conti, 2007). Most definitions also share the theme of "engaging in economically sustainable business activities that go beyond legal requirements to protect the well-being of employees, communities, and the environment" (Heslin \& Ochao, 2008). For example, the American Society for Quality (ASQ, 2007) has a comprehensive definition of CSR which is about assuring that "people and organisations behave ethically and with sensitivity toward social, cultural, economic and environmental issues".

Werther and Chandler (2010, p. xi) noted that CSR is referred to by different terms in different contexts, such as "Corporate Responsibility or Business Responsibility, Corporate Citizenship or Global Responsibility, Corporate Community Engagement, Community Relations, Corporate Stewardship, Social Responsibility and Strategic Philanthropy”.

In 2008, Montiel stated that there was a broad agreement on the social and environmental responsibilities of organisations, which have become core business issues, no matter how the overall concept of CSR is defined. Nevertheless, the process of categorising the dimensions of CSR may be more important than debate about the definitions of CSR. In this respect, Dahlsrud (2008) analysed the content of different CSR definitions and found five CSR dimensions: stakeholders, social, economic, voluntariness and environmental. These are not dissimilar to Carroll's (1979) four types of corporate responsibilities under the term CSR: economic, legal, ethical and philanthropic responsibility.

\section{Stakeholder Theory: Who Do SQM and CSR Serve?}

Stakeholder theory is often referred to in the CSR literature. A stakeholder is any group or individual who can affect the organisation or may be affected by it (Freeman \& Phillips, 2002). Stakeholder theory aims to explain the nature of the relationships between the organisation and its stakeholders (Benn \& Bolton, 2011, p. 196). However, it is a concept that has previously been explored in SQM as it became obvious that the relationship between an organisation and the direct purchaser of its product or service (i.e. the customer) was not the only relationship that was significant in achieving organisational excellence, particularly in the case of public and not-for-profit organisations (Reed, 1997, chapter 2). Instead there is a definite need to take into account and balance the needs and wishes of other interested parties too.

According to stakeholder theory, a socially responsible organisation "requires simultaneous attention to the legitimate interests of all appropriate stakeholders and has to balance such multiplicity of interests" (Garriga \& Melè, 2004, p. 60). Freeman (1984) had introduced the stakeholder model of shareholders, customers and suppliers, and government, civil society and competitors. In a later version (2003), further internal stakeholders and external groups were added (NGO's, environmentalists, governments, critics, media and others). Wood (2008) concluded that this stakeholder theory and framework could positively affect organisational CSR programmes by facilitating analysis of those parties and their stakes, to whom the organisation should be responsible. This stakeholder model has been refined and more details have been added; for example, the need to prioritise the various stakeholders. There are critical evaluations of the theory, which can be summarised as ambiguities in the concepts of stakeholder theory and their application in organisations and a lack of consistency in the 
literature of these concepts (Fassin, 2008, p. 115). Nevertheless, the stakeholder theory and model are very helpful for those who want to start making sense of CSR and its application in their companies with their different interested parties and the various Excellence models can provide initial direction.

\section{CSR theories and definition}

There are several theories that underpin the definitions of CSR, which vary in terms of their focus and approach to CSR and with the context and scope of each individual organisation (Hemingway, 2002, p. 5). On occasion, these seem to be contradictory. Garriga and Melè (2004) reviewed the theories of CSR and identified four types, dependent on focus and approach. These types are:

- Instrumental theories: where "it is assumed that the corporation is an instrument for wealth creation and that this is its sole social responsibility" (Garriga \& Melè, 2004, p. 52). This relates to Friedman's idea that the responsibilities of businesses are only to "conduct the business... to make as much money as possible while conforming to the basic rules of the society, both those embodied in law and those embodied in ethical customs" (Friedman, 1970 p. 1). This theory identifies three main foci: "maximization of shareholders values, achieving competitive advantages and cause-related marketing” (Garriga \& Melè, 2004, p. 53).

- Political theories: focus on the "interactions and connections between business and society and on the power and position of business and its inherent responsibility" (Garriga \& Melè, 2004, p. 55), based on three political theories: "corporate constitutionalism, social contract, corporate citizenship" (Garriga \& Melè, 2004, pp. 55-56). These build on Davis' view (1973, p. 321) that society is expecting more than profit maximisation from business and that businesses are aware of this greater level of expectation.

- Integrative theories: "look at how business integrates social demands, arguing that business depends on society for its existence, continuity and growth" (Garriga \& Melè, 2004, p. 57). The main principle is pursuing social demands and then responding to them and thereby achieving "... social legitimacy, greater social acceptance and prestige" (Garriga \& Melè, 2004, p. 58), building on stakeholder theory, as it is "intended to broaden management's vision of its role and responsibility beyond the profit maximization function" (Mitchell, Agle \& Wood, 1997, p. 855).

- Ethical theories: focus on the "ethical requirements that cement the relationship between business and society based on principles that express the right thing to do or the necessity to achieve a good society" (Garriga \& Melè, 2004, p. 60). Relevant theories are: normative stakeholders, universal rights, sustainable development and the common good (Garriga \& Melè, 2004, pp. 60-62). International standards, such as the United Nations Global Compact, are good examples of ways to apply this type of theory. In addition, Freeman and Phillips (2002, p. 333) support the ethical theories of CSR, suggesting that organisations should be stakeholder oriented, taking into account the views of all of the parties that might be affected by the organisation's decisions or actions, rather than simply targeting the shareholder.

Carroll (1991) conceptualised four levels of corporate responsibilities under CSR, where each level builds on the previous one: 
1. Economic responsibility: to be profitable.

2. Legal responsibility: to abide by the laws of society.

3. Ethical responsibility: to do what is right, fair and just.

4. Philanthropic responsibility: to contribute to various kinds of social activities.

Carroll's model had great impact and acceptance. However, Kang (1995) argued that showing economic responsibility as the first layer of the model was problematic, because it is too easy for organisations to focus on their economic responsibility and thereby justify compromising their ethical and legal responsibilities. More recently, Schwartz and Carroll (2003, p. 505) identified several issues with the model, such as "the use of a pyramid to depict the relationships among the four components of the model, the role of philanthropy as a separate component in the model, and the incomplete theoretical development of the economic, legal and ethical domains", which led them to propose a new model, The Three-Domain model of CSR, which addressed the limitations of Carroll's original model (1991). The Three-Domain model consists of three rather than four areas of responsibility - economic, legal and ethical, see Figure 1 - the original philanthropic responsibility being considered within either the ethical and/or economic domains (Schwartz \& Carroll, 2003, p. 508).

The domains of this model are explained as:

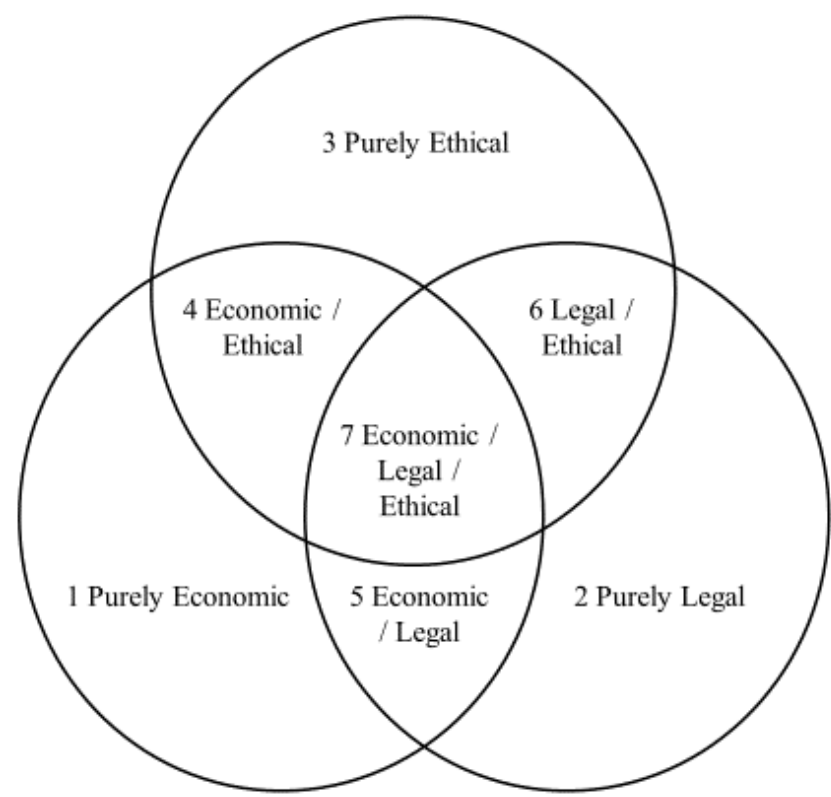

Figure 1: Three-Domain CSR Model (Source: Schwartz and Carroll (2003))

- Economic Domain: activities that have a positive economic impact. The actions of a corporation, within this domain, should be based on the maximisation of profit and share value or minimising of loss, also, all the actions should be made with consideration to the economic consequences (Schwartz \& Carroll, 2003, p. 509).

- Legal Domain: which is the corporation's responsiveness to the legal expectations of a society. Schwartz and Carroll (2003, p. 509) categorised legality as: 1) compliance with the laws, 2) avoidance of a possible "civil litigation", and 3) anticipation of changes in laws and regulations.

- Ethical Domain: which is about the ethical responsiveness that society and stakeholders expect from organisations. Schwartz and Carroll (2003, p. 511) identified three ethical 
categories: 1) conventional, which includes those standards that are accepted by organisations, industry, professions and society including the stakeholders; 2) consequentialist, which focuses on ends and consequences for individuals and society; and 3) deontological, which includes moral rights and justice (Schwartz \& Carroll, 2003, pp. 511-513).

According to this model, there are seven areas within which an organisation's CSR activities could be placed. These areas are: 1) purely economic, 2) purely legal, 3) purely ethical, 4) economic/ethical, 5) economic/legal, 6) legal/ethical, and 7) economic/legal/ethical. If an organisation places more emphasis on one domain than the other two, the area of that domain will be greater than the others and, as a result, the organisation will have an unbalanced model of CSR (Schwartz \& Carroll, 2003, p. 523). Thus, this categorisation could assist an organisation to balance its CSR efforts across its domains of responsibilities.

Organisations need to be able to measure and report to many different interested parties their CSR activities, efforts and outcomes and Wood (2010, pp. 53-54) proposed a model, Corporate Social Performance (CSP), to measure CSR activities, which was built on previous work, such as Carroll's study (1979) and earlier studies of CSP. Her model of the institutional, organisational and individual levels of performance consisted of three elements (see Figure 2):

1. Principles of social responsibility,

2. Process of social responsiveness, and

3. Outcomes and impacts of performance.

\begin{tabular}{|c|c|c|}
\hline $\begin{array}{l}\text { Principles of Social } \\
\text { Responsibility }\end{array}$ & Processes of Social Responsiveness & $\begin{array}{l}\text { Outcomes \& Impacts } \\
\text { of Performance }\end{array}$ \\
\hline $\begin{array}{l}\text { Legitimacy: businesses that } \\
\text { abuse the power society grants } \\
\text { them will lose that power }\end{array}$ & $\begin{array}{l}\text { Environmental Scanning: gather } \\
\text { the information needed to understand } \\
\& \text { analyse the firm's social, political, } \\
\text { legal \& ethical environments }\end{array}$ & $\begin{array}{l}\text { Effects on people \& } \\
\text { organisations }\end{array}$ \\
\hline $\begin{array}{l}\text { Public Responsibility: } \\
\text { Businesses that are responsible } \\
\text { for outcomes related to the } \\
\text { primary \& secondary areas of } \\
\text { involvement with society }\end{array}$ & $\begin{array}{l}\text { Stakeholder Management: active \& } \\
\text { constructive engagement in } \\
\text { relationships with stakeholders }\end{array}$ & $\begin{array}{l}\text { Effects on the natural } \\
\& \text { physical } \\
\text { environments }\end{array}$ \\
\hline $\begin{array}{l}\text { Managerial Discretion: } \\
\text { Managers \& other employees } \\
\text { are moral actors \& have a duty } \\
\text { to exercise discretion toward } \\
\text { socially responsible, ethical } \\
\text { outcomes }\end{array}$ & $\begin{array}{l}\text { Issues / Public Affairs } \\
\text { Management: a set of processes that } \\
\text { allow a company to identify, analyse } \\
\text { and act on the social or political } \\
\text { issues that may affect it significantly }\end{array}$ & $\begin{array}{l}\text { Effects on social } \\
\text { systems \& institutions }\end{array}$ \\
\hline
\end{tabular}

Figure 2: Wood's CSP Model (Source: Wood (2008))

It can be seen that there is correspondence between Schwarz and Carroll's (2003) domains and Wood's (2010) principles. This model has been further expanded by Aguinis and Glavas (2012, p. 952), "... based on a review of 588 journal articles and 103 books and book chapters" (p. 932), into a model that not only addresses the "what" and the "who", but also the predictors, mediators and possible outcomes of CSR approaches.

It could, perhaps, be said that the controversy in the literature concerning the definition, scope and evolution of CSR, has, to a great extent, been resolved and the term CSR, or more 
recently just CR, has been widely accepted in the academic field. But what about in the market or in practical thinking (Matten \& Crane, 2005, p. 167)? What effort has been put into building a practical understanding of the implementation of CSR and in assisting organisations to manage it? Dahlsrud's (2008) conclusion was that “...the problem with business is not so much to define CSR, as it is to understand how CSR is socially constructed in a specific context and how to take it into account when business strategies are developed" (p. 7). For this reason, this study asks the question: Could commonalities between SQM and CSR be the conduit that brings about this practical understanding of the implementation and management of CSR that fosters inclusion when business strategies are developed?

\section{SQM and CSR - the Relationship}

The underpinnings of Friedman (1970), Street \& Street (2010), Garriga \& Melè, (2004), Schwartz \& Carroll, (2003) and Kang (1995) were used to explore the possibility of leveraging the commonalities between SQM and CSR to perform a simplified CSR implementation. Thus, this study makes the following claims:

1. The integration of corporate strategy and TQM by way of the ISO 26000, 9000, 14000 and 18000 identifies what SQM really is.

2. CSR is made of three broad areas with central themes that previous research identified as profitability, legal and ethical.

3. Commonalties between SQM and CSR simplify an organisation's implementation of a CSR programme assuming the organisation has an existing SQM programme already in place.

Claims 1 and 2 are the premises to Claim 3 and the question introduced in this study earlier.

In terms of profitability, a CSR central theme mentioned in Claim 2, there is a consensus among the CSR literature used in this research that points to a clear reason for confining this study to organisations with existing SQM programmes in place, and a definitive meaning for the use of the word simplify in the guiding argument previously introduced in this study.

The reason for confining this study to organisations with existing SQM programmes lies in one of the common purposes of corporate strategy - the achievement of profitability (Hill \& Jones, 2009). However, adding QM activities as part of a corporate strategy of pursuing quality excellence, adds another dimension to profitability (George \& Weimerskirch, 1998, p.7). The new dimension of profitability acts as a measure of effectiveness, which implies an existing QM system. This added dimension to profitability provides a clear warrant to confine the scope of this study to organisations with existing SQM programmes in place and further aligns profitability with both SQM and CSR.

The fundamental teachings of corporate strategy links profitability to the achievement of competitive advantages (Hill \& Jones, 2009; Kaplan \& Norton, 2008). One of those competitive advantages as it relates to SQM, is the cost of quality assurance activities both inside and outside organisations (Porter, 1985). Porter (1985) further elaborated on the concept of competitive advantage by way of quality assurance activities when stating, "The possibility of simplifying or eliminating the need for quality assurance activities through performing other activities better is at the root of the notion that quality can be free" (p. 45). This study takes the understanding of the word simplify from Porter (1985) as it relates to a simplified CSR implementation among organisations with existing SQM programmes. 
To study the relationship between SQM and CSR, definitions are important, so to be clear, the type of CSR this paper focuses on relates to "engaging in economically sustainable business activities that go beyond legal requirements to protect the well-being of employees, communities, and the environment" (Heslin \& Ochao, 2008, p. 126), regardless of the terminological differences between the theories and definitions that share this theme.

Juran viewed SQM as "A systematic approach for setting and meeting quality goals throughout the company, it is the apex of the broader system of managing quality throughout the company" (cited in Leonard \& McAdam, 2002, p. 514). The application of SQM is about being competitive in the long-term, or sustainable, by implementing TQM with an emphasis on strategic dimensions in order to add more value to a wider circle of stakeholders. Evidence of improved results as a consequence of applying quality practices has encouraged their wide adoption by organisations (Sirvanci, 2004, p. 382; Boulter, Bendell \& Dahlgaard, 2013).

In the literature, interest in linking SQM and CSR arose after the ISO had announced its intention to introduce a CSR standard in 2004 (Castka \& Balzarova, 2007, p. 739) and has continued since the introduction of the ISO 26000:2010 standard (Sapru \& Schuchard, 2011, p. 2). This standard was launched in 2010. The International Organisation for Standardisation states that ISO 26000 "is intended for use by organizations of all types, in both public and private sectors, in developed and developing countries. It will assist them in their efforts to operate in the socially responsible manner that society increasingly demands" (ISO, 2008, p. 1). According to an ASQ paper (2007, pp. 4-5) the objectives of ISO 26000 are as follows:

- Assisting organisations to recognise their social responsibilities within their cultural, social, legal and economic environment.

- Assist organisations to integrate social responsibility to their operations.

- Relate the implementation of social responsibility to performance results and improvement.

- $\quad$ Provide a common terminology in social responsibility.

- Widen the awareness and understanding of social responsibility.

Meanwhile, Gravem (2010, p. 17) notes the core subjects and issues of social responsibility as they were identified by ISO, which are:

- Accountability.

- Transparency.

- $\quad$ Ethical behaviour at all times.

- $\quad$ Respect for stakeholder interest.

- $\quad$ Respect the rule of the law.

- Respect international norms of behaviour.

- Human rights.

The ISO 26000 standard contains guidance, not requirements, and it is not certifiable like other ISO standards such as ISO 9001, ISO 14001 (ISO, 2008, p. 1). However, it is suggested that in the future there will be some form of verification of compliance with ISO 26000, via some form of audit of CSR activities (Castka \& Balzarova, 2007, p. 748). With this standard, hopefully, organisations would be helped in committing to social responsibility generally, as well as maintaining opportunities for continuous improvement (ASQ, 2007, p. 4).

By 2011 ASQ were reporting that "much of what we call sustainability has deep roots in quality. ..... CSR grapples with energy efficiency, supply chain metrics, supplier engagement several tiers away, reduced waste, and keeping a strong focus on customer value, which in the 
quality world can be viewed as old challenges put in a new context and for a new era of increasingly networked and globalized operations" ASQ (2011, p. 2). One of the underpinning ideas of QM is that doing the right thing right the first time is always the least wasteful route and CSR could be viewed as a logical extension of that idea. Both SQM and CSR are based on the same set of core values and beliefs such as "doing the right thing, right", "meeting stakeholders' requirements" (Goetsch \& Davis, 2016), "do no harm", and "zero-waste" (ASQ, 2011 , p. 3). The quality systems perspective encourages organisations to use systematic approaches to plan, operate and evaluate, taking into account all interested parties (ASQ, 2007, p. 5).

Quality cannot be separated from CSR; they are close in both theory and practice, the two concepts are "intertwined, reinforcing one another's strengths" (Ascigil, 2010, p. 18). The linkage between CSR and QM, theoretically and practically, can be justified as follows:

1. QM has given CSR prominence within its theoretical frameworks and practical applications (Ascigil, 2010, p. 17).

2. Much of what is called CSR has its roots in QM (Sapru \& Schuchard, 2011, p. 2).

3. The similarities of the values, concepts and evolutionary nature of the two approaches (Ghobadian et al., 2007, p. 706).

4. The initiation of QM implementation can be considered as a responsible action (Ghobadian et al., 2007, p. 704).

CSR is probably still behind SQM in terms of the practicability and development. The next step for CSR is encouraging organisations to question how the concept might mesh with their systems and culture. After that, they will need help to develop practical tools and methods for implementation and performance evaluation. But guidance for this implementation of CSR is not yet as mature as those used in QM (Sapru \& Schuchard, 2011; Ghobadian et al., 2007; Zadek, 2007; Cramer, Jonker \& Heijden, 2004).

SQM models, such as the EFQM Excellence Model $^{1}$, the Malcolm Baldrige National Quality Award (MBNQA) framework, the Australian Business Excellence Framework and the Canadian Framework for Business Excellence, all include CSR as an essential element (Ghobadian et al., 2007, p. 714). Similarly, CSR criteria are obvious within the environment standard ISO 14000 and the quality management standard ISO 9000 (ASQ, 2007, p. 4). This brings CSR to the attention of organisations and greatly influences evolution of the understanding and application of CSR (Waddock \& Bodwell, 2004, p. 33). Moreover, recently there has been the development of the concept of a standardised management system for corporate sustainable development (Asif \& Searcy, 2014).

Quality tools have been widely used for leaning operations, reducing waste, improving efficiency and facilitating the effective use of resources; these are all areas of interest to CSR, although these tools have not been widely recognised as effective methods to be used to serve CSR objectives (Sapru \& Schuchard, 2011, p. 7). According to Fotopoulos and Psomas (2009, p. 151), SQM has both "soft" elements, which refer to management concepts and principles, and "hard" elements, which refer to the tools and techniques of quality improvement. CSR

${ }^{1}$ The EFQM Excellence Model is used as an exemplar, so that points highlighted via its citation should be assumed to be true also of other national Excellence or Quality award models. 
could make use of these "hard" elements to overcome its apparent lack of applicable management tools and techniques.

Furthermore, the SQM principle that employees should be treated as internal customers and the quality of the work environment, their health and safety, their overall satisfaction with their jobs and their wellbeing, should be considered, all of which can be derived from ISO 9000, ISO 14000, ISO 18000 and various excellence models. Likewise, models of CSR, such as UNGC, RCI and ISO 26000, emphasise the "rights of the employees". Moreover, according to Sapru \& Schuchard (2011, p. 3), ISO 26000 makes a deliberate connection between QM systems and human rights, labour policies and practice.

SQM has overcome many of the challenges surrounding the implementation of its values and has moved from being only a theoretical argument to being functional and practical, and some practitioners strongly believe that a number of quality tools and techniques can effectively assist organisations in addressing CSR issues and challenges and in implementing their CSR programmes (ASQ, 2007, p. 5). For instance, Liebesman (2004) suggested the implementation of ISO 9000 and ISO 14000 to achieve CSR principles such as reducing waste and minimising risk, and suggested that when taking advanced steps, it is wise to use more comprehensive and sophisticated quality frameworks such as the MBNQA. Castka and Balzarova (2007, p. 748) stated that the quality movement and quality practitioners could apply the knowledge, experience, tools, models and standards of quality to the implementation of CSR, particularly by providing fact-based grounds for action and analysis (ASQ, 2007, p. 5). Both SQM and CSR help to manage the relationship with the stakeholders; while SQM is about the endeavour to satisfy the stakeholders and to meet their expectations, CSR is helping to "stabilise mutual expectations among them" (Ascigil, 2010, p. 8).

There are several areas where SQM tools and methods can be used to achieve the same desired outcomes as CSR, for example (Sapru \& Schuchard, 2011, p. 6):

- Waste reduction: QM uses methods, such as lean manufacturing, six sigma and Justin-time to more effectively manage resource utilisation.

- Employees' involvement and empowerment: TQM frameworks and quality award models can be used to help to direct and encourage employees to engage with improvement activities.

- Governance: Auditing, quality control and quality assurance; self assessment.

- Internal alignment: Quality Function Deployment.

- Pro-activity: A preventive mind-set instead of a corrective one. Also, using tools to study the impact of the organisation on different aspects.

For instance, in terms of governance, SQM has practised auditing to evaluate processes against policies and standards and to assess conformity and nonconformity. Auditing is regarded as one of the main performance evaluation tools of quality management and it is a central part of the evaluation of QMS such as the ISO series (Karapetrovic \& Willborn, 2001, p. 366). From a CSR perspective, internal audit has proved to be one of the most effective methods for governance and for exposing frauds and other white-collar crime (Schnatterly, 2001, cited by Castka \& Balzarova, 2007, p. 746) leading Castka and Balzarova (2007, p. 748) to suggest that organisations could benefit from this quality tool by expanding the audit scope to cover CSR and Corporate Governance activities.

Transparency and accountability are strongly promoted by the CSR movement: another match with SQM. SQM encourages practices, such as no blame, open and fear-free cultures, 
that require exposing and reporting what companies are doing, activities that are closely related to transparency. SQM encourages sharing and communicating information with the stakeholders and by doing so, the organisation performs in a transparent manner; mistakes are viewed as opportunities to improve, with everyone taking responsibility for his/her own activities (Ghobadian et al., 2007, pp. 706-708).

In addition, transparency can assist learning and development and stakeholders' engagement with the organisation, which are again SQM characteristics. When an organisation is sharing and communicating information transparently, it allows the stakeholders to be involved and thus to provide their views, suggestions and complaints, which can be a source for learning and development and provide inputs to organisational decisions and strategies.

In the literature, the tendency is to study the relationship between SQM and CSR and usually addresses how similar they are and how SQM can benefit the CSR movement too. However, CSR has the potential to be beneficial to the SQM movement by introducing some important factors. For example, CSR can improve and broaden the strategic thinking within SQM. CSR takes into consideration future generations and their needs, while SQM mostly considers the needs of the present, although the models of excellence do address to some extent the needs of future customers. SQM thinking does not ignore the long-term view, but CSR offers even longer-term views by considering a wider circle of stakeholders and their needs and challenges.

According to Werther and Chandler (2013, pp. 85-86), leaders always find themselves in a situation where they need to decide about the methods they use and the results they obtain, a situation that always pertains. Here CSR can play a strategic role as a filter of the decisions between different organisational levels; it will support the overall organisational strategic position and decisions. Therefore, CSR could widen the strategic vision of SQM holistically by offering different perspectives of elements to which SQM may give less priority, thus, enriching the process of decision-making. Nevertheless, incorporating SQM and CSR together requires a change in the strategic mindset of organisations; for some organisations this will be a radical change, for others it will be incremental. This strategic alliance between these two areas can, it could be said, lead to a sustainable future built on QM principles (Kuei \& Lu, 2013), though the findings of this analysis indicate that having established SQM gives a definite head start in launching CSR.

Reviewing the relationship between SQM and CSR, Ghobadian et al., (2007, pp. 714717) concluded that, despite the overlap and similarities between SQM and CSR, there are still differences, so CSR will not necessarily exist in an organisation just because it has SQM in place.

To strengthen the connection and make it more practical and beneficial, there is a need to broaden the scope of SQM by including CSR elements. According to Ghobadian et al., (2007, p. 717) "the outcomes at individual level are not precisely the same", and they emphasised that the two concepts should be integrated and the elements of CSR explicitly addressed. This was similar to the suggestion of Garvare and Isaksson (2001, pp. 14-15) that an organisation could extend its awareness and efforts in CSR by adding its components to the requirements of the adopted excellence model, thus making the CSR elements more adaptable and measurable. By doing this, CSR will use SQM as a "vehicle for expediting the diffusion of CSR" (Ghobadian et al., 2007, p. 717). 


\section{The Business Case for CSR Implementation}

It is reasonable for businesses to attempt to find the link between any new business initiative and the fundamental concept of profitability, and CSR is no exception. Whatever the reasons organisations use to commit to CSR implementation, they inevitably balance their CSR programmes against profitability (Castka \& Balzarova, 2007). Thus, many organisations have described CSR within their annual reports (ASQ, 2007). However, in many cases what was reported was not the outcomes of the CSR practices, but rather the organisation's efforts and activities in relation to various CSR dimensions.

As the planning and practice of CSR matures it can become a principal contributor to the competitiveness of an organisation. Porter \& Kramer (2006) suggested that organisations should seek competitive advantages from their CSR practices by linking these practices to strategy and core business operations. They argued that the competitiveness of organisations in the current business environment will be strongly linked to their commitment to and performance of CSR.

Both companies and researchers continue to attempt to identify tangible benefits from the integration of the CSR concepts with the key organisational processes, especially in financial terms. This is approach has led to literature that addresses the "business case for CSR", discussing whether the market will reward organisations which have CSR activities in place (Carroll \& Shabana, 2010). Some researchers insist on viewing CSR as any other investment and expect a financial return from CSR activities (Castka, Bamber, Bamber \& Sharp, 2004). The results are inconclusive and vary from reflecting profitability, to a cost with no return and/or neutral findings (McWilliams \& Siegel, 2000; Shahin \& Zairi, 2007). However, Wood (2010) stated that CSR should not be seen as an add-on but rather as a moral imperative that underpins a business's right to operate.

Halme and Laurila (2009) attempted to systematically analyse the financial and societal effects of CSR. They distinguished between three different types of CSR:

1. "Philanthropy: emphasis on charity, sponsorship, employee voluntarism, etc.

2. CR Integration: emphasis on conducting existing business operations more responsibly.

3. CR Innovation: emphasis on developing new business models for solving social and environmental problems".

Carroll and Shabana (2010) also note that the business case for CSR has both narrow and broad views. The narrow view attempts to link CSR activities directly with the Corporate Financial Performance (CFP), whereas the broader view recognises the direct and indirect impacts of CSR activities on overall corporate performance and looks for a balance between the societal benefits and the benefits accruing to companies that hopefully lead to financial and economic results; for example: cost and risk reduction, reputation in the market and the community, innovation and synergy with the stakeholders, and increased employee motivation (Wood, 2010; Kurucz, Colbert \& Wheeler, 2008; Kytle \& Ruggie, 2005). Many of these benefits are also to be found in the model suggested by Aguinis \& Glavas (2012).

\section{Integration strategy}

The discussion above reviewed the elements of SQM and their relationships to aspects of CSR. Table 1 summarises the areas discussed in this review and classifies them to illustrate the similarities and differences between these two concepts. In addition, Table 1 shows that the 
relationship between SQM and CSR is not about adding components to one another; rather it is more about the different overall viewpoint that a combination of SQM and CSR would offer. This is analogous to the benefits that binocular vision gives in the ability to perceive depth. The elements in the table are sequenced with conceptual points first, followed by more practical items through which delivery might be achieved. 
Table 1: Synergies between SQM and CSR

\begin{tabular}{|c|c|c|c|c|}
\hline Elements & SQM & CSR & Comment & Reference \\
\hline Strategic mindset & $\checkmark$ & $\checkmark$ & $\begin{array}{l}\text { Both SQM and CSR } \\
\text { encompass a strategic vision, } \\
\text { but whereas business strategies } \\
\text { tend to use a } 10-20 \text { year } \\
\text { horizon, some elements of } \\
\text { CSR (particularly the } \\
\text { environmental) may take an } \\
\text { even longer view. }\end{array}$ & $\begin{array}{l}\text { Kuei \& Lu (2013); } \\
\text { EFQM \& other } \\
\text { Excellence Models; } \\
\text { Juran }\end{array}$ \\
\hline $\begin{array}{l}\text { Clarity of theory and } \\
\text { practice }\end{array}$ & $\checkmark$ & & $\begin{array}{l}\text { CSR has opportunities to build } \\
\text { on experience from successful } \\
\text { implementation of SQM. }\end{array}$ & $\begin{array}{l}\text { Ascigil (2010); ISO } \\
\text { Standards }\end{array}$ \\
\hline $\begin{array}{l}\text { Broad focus on } \\
\text { stakeholders }\end{array}$ & $\checkmark$ & $\checkmark$ & $\begin{array}{l}\text { More important in CSR, } \\
\text { although the SQM Excellence } \\
\text { Models do encourage a broader } \\
\text { focus. }\end{array}$ & $\begin{array}{l}\text { Carroll \& Shabana } \\
\text { (2010); Halme \& } \\
\text { Laurila (2009); Reed } \\
\text { (1997) }\end{array}$ \\
\hline $\begin{array}{l}\text { Considerations for } \\
\text { future generations }\end{array}$ & & $\checkmark$ & $\begin{array}{l}\text { CSR does not just consider the } \\
\text { success / survival of the } \\
\text { organisation, but also its long- } \\
\text { term role in the long-term } \\
\text { wellbeing of society and the } \\
\text { environment. }\end{array}$ & $\begin{array}{l}\text { Werther \& Chandler } \\
(2013) \text {; Kuei \& Lu } \\
(2013)\end{array}$ \\
\hline $\begin{array}{l}\text { Focus on impact of } \\
\text { activities }\end{array}$ & $\checkmark$ & $\checkmark$ & $\begin{array}{l}\text { While SQM considers the } \\
\text { impact on a range of } \\
\text { stakeholders, both internal and } \\
\text { external, CSR adds a more } \\
\text { detailed assessment of } \\
\text { heretofore nebulous } \\
\text { stakeholders, such as "society" } \\
\text { and "the environment". }\end{array}$ & $\begin{array}{l}\text { Carroll \& Shabana } \\
(2010)\end{array}$ \\
\hline Environmental focus & $\checkmark$ & $\checkmark$ & $\begin{array}{l}\text { "The total quality loss of a } \\
\text { product is the sum of the total } \\
\text { monetary loss and the } \\
\text { environmental effects the } \\
\text { product contributes during its } \\
\text { entire life" (Taguchi, 1995, p. } \\
\text { 225). }\end{array}$ & $\begin{array}{l}\text { Taguchi (1995); } \\
\text { EFQM \& other } \\
\text { Excellence Models }\end{array}$ \\
\hline Doing no harm & $\checkmark$ & $\checkmark$ & $\begin{array}{l}\text { Implied in SQM, but stated } \\
\text { explicitly in CSR. }\end{array}$ & $\begin{array}{l}\text { Goetsch \& Davis } \\
(2016)\end{array}$ \\
\hline Waste reduction & $\checkmark$ & $\checkmark$ & $\begin{array}{l}\text { More clearly articulated in } \\
\text { CSR, also CSR takes a less } \\
\text { parochial view of where waste } \\
\text { might occur. }\end{array}$ & $\begin{array}{l}\text { Goetsch \& Davis } \\
\text { (2016); Sapru \& } \\
\text { Schuchard (2011) }\end{array}$ \\
\hline $\begin{array}{l}\text { Employees rights } \\
\text { and satisfaction }\end{array}$ & $\checkmark$ & $\checkmark$ & $\begin{array}{l}\text { Addressed within the "people" } \\
\text { (employee) aspects of both the } \\
\text { standards and models. }\end{array}$ & $\begin{array}{l}\text { Sapru \& Schuchard } \\
\text { (2011); EFQM \& other } \\
\text { Excellence Models; } \\
\text { ISO Standards }\end{array}$ \\
\hline
\end{tabular}




\begin{tabular}{|c|c|c|c|c|}
\hline Health and safety & $\checkmark$ & $\checkmark$ & $\begin{array}{l}\text { Addressed within the "people" } \\
\text { (employee) aspects of both the } \\
\text { standards and models. }\end{array}$ & $\begin{array}{l}\text { Sapru \& Schuchard } \\
\text { (2011); EFQM \& other } \\
\text { Excellence Models; } \\
\text { ISO Standards } \\
\end{array}$ \\
\hline Governance & $\checkmark$ & $\checkmark$ & $\begin{array}{l}\text { Addressed within SQM models } \\
\text { and standards, but given a } \\
\text { more distinct justification by } \\
\text { CSR's focus on the needs of } \\
\text { wider society. }\end{array}$ & $\begin{array}{l}\text { Sapru \& Schuchard } \\
\text { (2011) }\end{array}$ \\
\hline Transparency & $\checkmark$ & $\checkmark$ & $\begin{array}{l}\text { Addressed within SQM models } \\
\text { and standards, but given a } \\
\text { more distinct justification by } \\
\text { CSR's focus on the needs of } \\
\text { wider society. }\end{array}$ & $\begin{array}{l}\text { Ghobadian \& Hopkins } \\
\text { (2007) }\end{array}$ \\
\hline Accountability & $\checkmark$ & $\checkmark$ & $\begin{array}{l}\text { Addressed within SQM models } \\
\text { and standards, but given a } \\
\text { more distinct justification by } \\
\text { CSR's focus on the needs of } \\
\text { wider society. }\end{array}$ & $\begin{array}{l}\text { Ghobadian \& Hopkins } \\
\text { (2007) }\end{array}$ \\
\hline Pro-activity & $\checkmark$ & $\checkmark$ & $\begin{array}{l}\text { Both approaches need to be } \\
\text { pro-active and future-oriented } \\
\text { to be effective. }\end{array}$ & $\begin{array}{l}\text { Sapru \& Schuchard } \\
\text { (2011) }\end{array}$ \\
\hline $\begin{array}{l}\text { Learning and } \\
\text { Development }\end{array}$ & $\checkmark$ & $\checkmark$ & $\begin{array}{l}\text { More explicit in SQM, but } \\
\text { clearly applicable in CSR } \\
\text { activities; especially } \\
\text { encouraged in Excellence } \\
\text { Models, originating from } \\
\text { PDCA cycle and focus on } \\
\text { Knowledge Management and } \\
\text { Organisational Learning. }\end{array}$ & $\begin{array}{l}\text { Ghobadian \& Hopkins } \\
\text { (2007) ; EFQM \& } \\
\text { other Excellence } \\
\text { Models }\end{array}$ \\
\hline $\begin{array}{l}\text { Systematic } \\
\text { processes }\end{array}$ & $\checkmark$ & & $\begin{array}{l}\text { A fundamental of both Quality } \\
\text { Standards and Excellence } \\
\text { Models. }\end{array}$ & $\begin{array}{l}\text { ASQ (2007); ISO } \\
\text { Standards; EFQM \& } \\
\text { other Excellence } \\
\text { Models }\end{array}$ \\
\hline Tools availability & $\checkmark$ & $\checkmark$ & $\begin{array}{l}\text { Standards, GRI, UN Compact, } \\
\text { etc. }\end{array}$ & $\begin{array}{l}\text { Sapru \& Schuchard } \\
\text { (2011); ASQ (2007) }\end{array}$ \\
\hline
\end{tabular}

The integration of CSR programmes, for example, based on ISO 26000, come via sequential steps following initial integrations of ISO 9000 and 14001 into quality management systems (QMS) (Searcy et al., 2012; Marques et al., 2013; Casadeús, Karapetrovic \& Heras, 2011; Jorgensen, Remmen \& Mellado, 2006). Sivaram et al. (2014) suggest the integration of ISO 9000 with a QMS achieves better operational performance, competitiveness via cost savings and synergies. Searcy et al. (2012) identified critical synergies between ISO 14001 and management system elements.

Casadeús et al. (2011) advocate organisations to be more than just ISO certificate holders. These organisations must integrate activities that afforded them their ISO certifications into a QMS, thereby leveraging synergies throughout their cost structures. This process of integration is not an easy process; one can expect departmentalisation of functions, lack of framework and 
human resources among other typical team conflict issues (Simon, Karapetrovic \& Casadeús, 2012). However, these issues also bring exposure and solutions early on that can be leveraged when the time comes for ISO 26000 implementation. Furthermore, these issues reinforce the consensus of prior literature that suggest integrating ISO 9000 and 14001 activities into a QMS prior to implementing ISO 26000 or a CSR programme onto existing SQM.

Integration, as a strategy to amalgamate more than one standard or system, is a common practice that helps organisations in the management and evaluation of those standards and systems. It is evident that the integration of two structures/standards/frameworks/models and their concepts should not pose major problems if they have significant commonalities. Indeed, integration in this situation is beneficial as it reduces costs and ensures better alignment of the organisation's systems and functions (Karapetrovic, 2002; Porter, 1985).

This could be applied to the case of the integration of SQM and CSR, however, as Rocha, Searcy \& Karapetrovic (2007) stated, it is difficult: “...lack of a framework to integrate sustainable development into mainstream business process is one of the biggest gaps preventing its implementation at the organisational level" (p. 84). But it would seem that such frameworks are beginning to arise, although a gap still remains and therefore efforts to contribute to knowledge in this area are required (Kuei \& Lu, 2013; Asif \& Searcy, 2014; Simon et al., 2012).

\section{Conclusions}

In conclusion, this study has explored literature to answer its guiding question:

How may the synergies between SQM and CSR simplify an organisation's implementation of CSR when SQM is already in place?

Initially, it clarified how SQM is identified and what CSR means by way of definitions, theories, approaches and types from experts in the field. It was established at the outset that SQM is identified when TQM via ISO activities and practices are inculcated with corporate strategies. The definition of CSR provided by Heslin \& Ochao, (2008) was the understanding of CSR embraced in this study and used to build elements that related to aims of ISO 9000, 14001 and 18000. Table 1 established the commonalities between SQM and CSR, both at conceptual and implementational levels and leads to the following conclusions.

1. An organisation using SQM will already be familiar with and, at least to some extent, acting upon concepts critical to CSR.

2. An established SQM programme provides the underpinning structure necessary to support CSR. This may be implemented via the use of ISO certification activities (9000, 14001 and 18000) to deliver a QMS.

3. Many of the approaches and tools familiar from SQM are directly applicable within a CSR implementation, thus reducing the learning curve for all involved.

4. The learning achieved as SQM progresses and retained in a QMS provides the body of knowledge needed for implementation of a CSR programme (ISO 26000). Thus lessons previously learned from SQM implementation can be leveraged.

5. Through the existing SQM system, progress will already have been made in many facets of CSR. Thus, some degree of buy-in to the spirit of CSR will already have been achieved in the organisation. 


\section{References}

Acquier, A., Valiorgue, B., \& Daudigeos, T. (2017). Sharing the Shared Value: A Transaction Cost Perspective on Strategic CSR Policies in Global Value Chains. Journal of Business Ethics, 144(1), 139-152. http://doi.org/10.1007/s10551-015-2820-0

Aguinis, H. \& Glavas, A. (2012) What We Know and Don't Know about Corporate Social Responsibility: A Review and Research Agenda, Journal of Management, 38(4), 932968, DOI: $10.1177 / 0149206311436079$

American Society for Quality (ASQ) (2007). Common Ground: Quality and Social Responsibility. Milwaukee: ASQ.

American Society for Quality (ASQ) (2011) Quality and Social Responsibility. Milwaukee: ASQ.

Aşcıgil, S. F. (2010). Toward socially responsible SMEs? Quality award model as a tool. Quality Management Journal, 17(3). 7-20. (No DOI).

Asif, M. \& Searcy, C. (2014) Towards a standardised management system for corporate sustainable development, The TQM Journal, 26(5), 411-430, DOI: 10.1108/TQM-082012-0057

Basu, K. \& Palazzo, G. (2008). Corporate social responsibility: A process model of sensemaking. Academy of Management Review, 33(1), 122-136. DOI: 10.5465/AMR.2008.27745504

Benn, S. \& Bolton, D. (2011). Key concepts in corporate social responsibility: Sage, London.

Black, S. A. \& Porter, L. J. (1996). Identification of the Critical Factors of TQM. Decision Sciences, 27(1), 1-21. DOI: 10.1111/j.1540-5915.1996.tb00841.x

Boulter, L., Bendell, T. \& Dahlgaard, J. (2013) Total quality beyond North America: A comparative analysis of the performance of European Excellence Award winners. International Journal of Operations \& Production Management, 33(2), 197-215, DOI: $10.1108 / 01443571311295635$

British Standards Institute (2015) BS EN ISO 9000:2015, Quality Management Systems. Fundamentals and Vocabulary. Retrieved from https://bsol.bsigroup.com

Bucur, M., Maior, P. \& Mureş, T. (2013). The csr implementation. Universitatea Petru Maior, 10(2), 70-75.

Carroll, A. B. (1979). A three-dimensional conceptual model of corporate performance. Academy of Management Review, 497-505. DOI: 10.5465/AMR.1979.4498296.

Carroll, A. B. (1991). The Pyramid of Corporate Social Responsibility: Toward the Moral Management of Organizational Stakeholders. Business Horizons. DOI: 10.1016/00076813(91)90005-G

Carroll, A. B. (1999). Corporate social responsibility evolution of a definitional construct. Business \& Society, 38(3), 268-295. DOI: 10.1177/000765039903800303

Carroll, A. B. \& Shabana, K. M. (2010). The business case for corporate social responsibility: a review of concepts, research and practice. International Journal of Management Reviews, 12(1), 85-105. DOI: 10.1111/j.1468-2370.2009.00275.x

Casadesús, M., Karapetrovic, S. \& Heras, I. (2011). Synergies in standardized management systems: some empirical evidence. The TQM Journal, 23(1), 73-86.

http://doi.org/10.1108/17542731111097506

Castka, P. \& Balzarova, M. A. (2007). A critical look on quality through CSR lenses: Key challenges stemming from the development of ISO 26000. International Journal of Quality \& Reliability Management, 24(7), 738-752. DOI: 10.1108/02656710710774700

Castka, P., Bamber, C. J., Bamber, D. J. \& Sharp, J. M. (2004). Integrating corporate social responsibility (CSR) into ISO management systems - in search of a feasible CSR management system framework. The TQM Magazine, 16(3), 216-224. DOI: 
$10.1108 / 09544780410532954$

Conti, T. A. (2007). A history and review of the European Quality Award Model. The TQM Magazine, 19(2), 112-128. DOI: 10.1108/09544780710729962

Cramer, J., Jonker, J. \& van der Heijden, A. (2004). Making sense of corporate social responsibility. Journal of Business Ethics, 55(2), 215-222. DOI: 10.1007/s10551-0041903-0

Crosby, P. B. (1979). Quality Is Free: The Art of Making Quality Certain. New American Library, New York.

Dahlsrud, A. (2008). How corporate social responsibility is defined: an analysis of 37 definitions. Corporate social responsibility and environmental management, 15(1), 113. DOI: $10.1002 / \mathrm{csr} .132$

Dale, B. G., Bamford, D. \& van der Wiele, T (2016). Managing Quality. (6 ${ }^{\text {th }}$ ed.) Oxford: Wiley.

Davis, K. (1973). The case for and against business assumption of social responsibilities. Academy of Management Journal, 16(2), 312-322. DOI: 10.2307/255331

Deming, Edward, W. (1994). The New Economics For Industry, Government, Education. (MIT Press, Ed.) (2nd ed.). Cambridge: MIT.

Fassin, Y. (2009). The stakeholder model refined. Journal of Business Ethics, 84(1), 113-135. DOI: $10.1007 / \mathrm{s} 10551-008-9677-4$

Feigenbaum, A.V. \& Feigenbaum, D. (2003). The power of management capital: utilizing the new drivers of innovation, profitability, and growth in a demanding global economy. New York: McGraw Hill.

Fotopoulos, C. B. \& Psomas, E. L. (2009). The impact of "soft" and "hard" TQM elements on quality management results. International Journal of Quality \& Reliability Management, 26(2), 150-163. DOI: 10.1108/02656710910928798

Freeman, E. (1984). "Strategic Management: A Stakeholder Approach", Pitman, Boston.

Freeman, E. (2003). Lecture-stakeholder management revisited: What's the state of the art? Leuven, 20 November.

Freeman, R. E. \& Phillips, R. A. (2002). Stakeholder theory: A libertarian defense. Business Ethics Quarterly, 331-349. DOI: 10.2307/3858020

Friedman, M. (1970). The social responsibility of business is to increase its profits. New York Times Magazine, September 13, 1970. (No DOI).

Garriga, E. \& Melé, D. (2004). Corporate social responsibility theories: mapping the territory. Journal of Business Ethics, 53(1-2), 51-71. DOI: 10.1023/B:BUSI.0000039399.90587.34

Garvare, R. \& Isaksson, R. (2001). Sustainable development: extending the scope of business excellence models. Measuring Business Excellence, 5(3), 11-15. DOI: 10.1108/13683040110403899

George, S. \& Weimerskirch, A. (1998). Total Quality Management: Strategies and Techniques Proven at Today's Most Successful Companies (2nd ed.). John Wiley \& Sons, Ltd.

Ghobadian, A., Gallear, D. \& Hopkins, M. (2007). TQM and CSR nexus. International Journal of Quality \& Reliability Management, 24(7), 704-721. DOI: 10.1108/02656710710774683

Goetsch, D. L. \& Davis, S. B. (2016). Quality management for organizational excellence $\left(8^{\text {th }}\right.$ ed.). New Jersey, Pearson.

Halme, M. \& Laurila, J. (2009). Philanthropy, integration or innovation? Exploring the financial and societal outcomes of different types of corporate responsibility. Journal of Business Ethics, 84(3), 325-339. DOI: 10.1007/s10551-008-9712-5

Hemingway, C. A. (2002). An exploratory analysis of corporate social responsibility: 
definitions, motives and values. University of Hull, Hull, UK.

Heslin, P. \& Ochoa, J. (2008). Understanding and developing strategic corporate social responsibility. Organizational Dynamics, 37, 125-144. (No DOI).

Hill, C. W. L. \& Jones, G. R. (2009). Theory of Strategic Management with Cases. (L. Johnson, C. Merrigan, \& K. White, Eds.) (8th ed.). South Western - Cengage Learning. Retrieved from international.cengage.com

ISO (2008) ISO and Social Responsibility, Retrieved from https://www.iso.org/files/live/sites/isoorg/files/archive/pdf/en/socialresponsibility.pdf

Johnson, G., Whittington, R., Scholes, K. \& Pyle, S. (2011). Exploring strategy: text \& cases. Harlow: Financial Times Prentice Hall.

Jørgensen, T. H., Remmen, A. \& Mellado, M. D. (2006). Integrated management systems three different levels of integration. Journal of Cleaner Production, 14(8), 713-722. http://doi.org/10.1016/j.jclepro.2005.04.005

Juran, J.M. \& De Feo, J. A. (2010). Juran's The Quality Handbook: The Complete Guide to Performance Excellence (6th ed.). New York: McGraw Hill.

Juran, J.M. (1989) Juran on Leadership for Quality. New York: The Free Press.

Kang, Y. C. (1995). Before-profit CSR, stakeholder capitalism and just enterprise system. Pittsburgh: University of Pittsburgh.

Kaplan, R. S. \& Norton, D. P. (2008). The Execution Premium: Linking Strategy to Operations for Competitive Advantage. Boston: Harvard Business School Publishing.

Retrieved from permissions@hbsp.harvard.edu

Karapetrovic, S. (2002). Strategies for the integration of management systems and standards. The TQM Magazine, 14(1), 61-67. DOI: 10.1108/09544780210414254

Karapetrovic, S. \& Willborn, W. (2001). Audit and self-assessment in quality management: comparison and compatibility. Managerial Auditing Journal, 16(6), 366-377. DOI: $10.1108 / 02686900110395505$

Karthi, S., Devadasan, S. R. \& Murugesh, R. (2011). Integration of Lean Six- Sigma with ISO 9001:2008 standard. International Journal of Lean Six Sigma, 2(4), 309-331. http://doi.org/10.1108/20401461111189416

Kim, Y. (2017). Consumer Responses to the Food Industry's Proactive and Passive Environmental CSR, Factoring in Price as CSR Tradeoff. Journal of Business Ethics, 140(2), 307-321. http://doi.org/10.1007/s10551-015-2671-8

Kuei, C-H. \& Lu, M.H. (2013) Integrating quality management principles into sustainability management, Total Quality Management, 24/1, 62-78, DOI:

10.1080/14783363.2012.669536

Kurucz, E. C., Colbert, B. A. \& Wheeler, D. (2008). The Business Case for Corporate Social Responsibility. In A. Crane, D. Matten, A. McWilliams, J. Moon \& D. S. Siegel (Eds) The Oxford Handbook of Corporate Social Responsibility, 83. DOI

10.1093/oxfordhb/9780199211593.003.0004

Kytle, B. \& Ruggie, J. G. (2005). Corporate social responsibility as risk management: a model for multinationals, Corporate Social Responsibility Initiative Working Paper 10. (No DOI).

Leonard, D. \& McAdam, R. (2002). Developing strategic quality management: a research agenda. Total Quality Management, 13(4), 507-522. DOI: 10.1080/09544120220149304

Leonard, D. \& McAdam, R. (2004). Total quality management in strategy and operations: dynamic grounded models. Journal of Manufacturing Technology Management, 15(3), 254-266. http://doi.org/10.1108/17410380410523489

Liebesman, S. (2004). Quality practitioners and effective corporate governance. Quality Progress, 37(3), 74-76. (No DOI). 
Maon, F., Lindgreen, A. \& Swaen, V. (2009). Designing and Implementing Corporate Social Responsibility: An Integrative Framework Grounded in Theory and Practice. Journal of Business Ethics, 87(Supplement 1), 71-89. DOI: 10.1007/s10551-008-9804-2

Marques, P., Requeijo, J., Saraiva, P. \& Frazão- Guerreiro, F. (2013). Integrating Six Sigma with ISO 9001. International Journal of Lean Six Sigma, 4(1), 36-59. http://doi.org/10.1108/20401461311310508

Matten, D. \& Crane, A. (2005) Corporate Citizenship: Toward an Extended Theoretical Conceptualization. Academy of Management Review, 30(1), 166-179. DOI: 10.5465/AMR.2005.15281448

Matten, D. \& Moon, J. (2008). "Implicit" and "explicit" CSR: A conceptual framework for a comparative understanding of corporate social responsibility. Academy of Management Review, 33(2), 404-424. DOI: 10.5465/AMR.2008.31193458

Mitchell, R. K., Agle, B. R. \& Wood, D. J. (1997). Toward a theory of stakeholder identification and salience: Defining the principle of who and what really counts. Academy of Management Review, 22(4), 853-886. DOI: 10.5465/AMR.1997.9711022105

Montiel, I. (2008). Corporate social responsibility and corporate sustainability separate pasts, common futures. Organization \& Environment, 21(3), 245-269. DOI: $10.1177 / 1086026608321329$

Porter, M. E. (1985). Competitve Advantage: Creating and Sustaining Superior Performance (First Free). New York: The Free Press.

Porter, M. E. \& Kramer, M. R. (2006). Strategy and society: the link between competitive advantage and corporate social responsibility. Harvard Business Review, 84(12), 78-92. (No DOI).

Reed, D. M. (1997). An investigation into the applicability of self assessment against the Business Excellence Model in UK Public Sector Organisations. University of the West of England, PhD Thesis, June 1997.

Rocha, M., Searcy, C. \& Karapetrovic, S. (2007). Integrating sustainable development into existing management systems. Total Quality Management \& Business Excellence, 18(12), 83-92. DOI: 10.1080/14783360601051594

Sapru, R. \& Schuchard, R. (2011). CSR and Quality: A Powerful and Untapped Connection. ASQ and BSR Quality Press. (No DOI).

Schwartz, M. S. \& Carroll, A. B. (2003). Corporate social responsibility: a three-domain approach. Business Ethics Quarterly, 13(4), 503-530. DOI: 10.5840/beq200313435

Searcy, C., Morali, O., Karapetrovic, S., Wichuk, K., McCartney, D., McLeod, S. \& Fraser, D. (2012). Challenges in implementing a functional ISO 14001 environmental management system. International Journal of Quality \& Reliability Management, 29(7), 779-796. http://doi.org/10.1108/02656711211258526

Shahin, A. \& Zairi, M. (2007). Corporate governance as a critical element for driving excellence in corporate social responsibility. International Journal of Quality \& Reliability Management, 24(7), 753-770. DOI: 10.1108/02656710710774719

Shewhart. W. A. (1931) Economic Control of the Manufactured Product. New York: D Van Nostrand Company.

Simon, A., Karapetrovic, S. \& Casadesús, M. (2012). Difficulties and benefits of integrated management systems. Industrial Management \& Data Systems, 112(5), 828-846. http://doi.org/10.1108/02635571211232406

Sirvanci, M. B. (2004). Critical issues for TQM implementation in higher education. The TQM Magazine, 16(6), 382-386. DOI: 10.1108/09544780410563293

Sivaram, N. M., Devadasan, S. R., Murugesh, R., Karthi, S. \& Sreenivasa, C. G. (2014). Synergising total productive maintenance elements with ISO 9001:2008 standard based 
quality management system. The TQM Journal, 26(6), 534-549.

http://doi.org/10.1108/TQM-08-2012-0059

Street, M. D. \& Street, V. L. (2010). Business and Society. In TAKING SIDES: Clashing Views in Management (3rd ed., pp. 4-12). New York: McGraw Hill.

Taguchi, G. (1990) Introduction to Quality Engineering: Designing Quality into Products and Processes. Asian Productivity Organisation.

Taguchi, G (1995) Quality Engineering (Taguchi Methods) For The Development Of Electronic Circuit Technology, IEEE Transactions On Reliability, 44(2)

Waddock, S. \& Bodwell, C. (2004). Managing responsibility: what can be learned from the quality movement? California Management Review, 47(1), 25-37. DOI: $10.2307 / 41166285$

Werther Jr, W. B. \& Chandler, D. (2010). Strategic corporate social responsibility: Stakeholders in a global environment. California: Sage Publications Incorporated.

Wood, D. J. (2010). Measuring corporate social performance: a review. International Journal of Management Reviews, 12(1), 50-84. DOI: 10.1111/j.1468-2370.2009.00274.x

Wood, D. J. (2008). Corporate Responsibility and Stakeholder Theory: Challenging the newclassical paradigm, in Agle, B.R., Donaldson, T., Freeman, R.E., Jensen, M.C., Mitchell, R.K. \& Wood, D. (eds), 'Dialogue: Toward Superior Stakeholder Theory', Business Ethics Quarterly, 19(2), 153-190. DOI: 10.5840/beq200818214

Zadek, S. (2007). The path to corporate responsibility. In W. C. Zimmerli, M. Holzinger \& K. Richter Corporate ethics and corporate governance, 159-172. Springer.

Zwetsloot, G. I. J. M. (2003). From management systems to corporate social responsibility. Journal of Business Ethics, 44(2), 201-208. DOI: 10.1023/A:1023303917699 